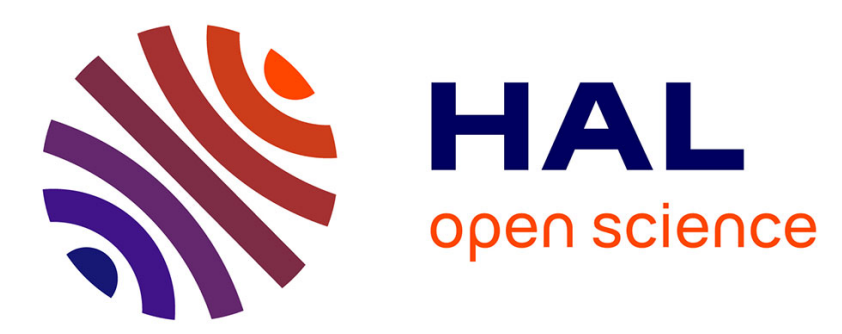

\title{
Antioxidant plant metabolites affect leaching of mineral elements from Callovo-Oxfordian clays
}

Dimitri Ubersfeld, Corinne Leyval, Paul-Olivier Redon, Christian Mustin

\section{To cite this version:}

Dimitri Ubersfeld, Corinne Leyval, Paul-Olivier Redon, Christian Mustin. Antioxidant plant metabolites affect leaching of mineral elements from Callovo-Oxfordian clays. European Journal of Soil Science, 2018, 69 (2), pp.348-359. 10.1111/ejss.12505 . hal-01857787

\section{HAL Id: hal-01857787 \\ https://hal.univ-lorraine.fr/hal-01857787}

Submitted on 1 Apr 2019

HAL is a multi-disciplinary open access archive for the deposit and dissemination of scientific research documents, whether they are published or not. The documents may come from teaching and research institutions in France or abroad, or from public or private research centers.
L'archive ouverte pluridisciplinaire HAL, est destinée au dépôt et à la diffusion de documents scientifiques de niveau recherche, publiés ou non, émanant des établissements d'enseignement et de recherche français ou étrangers, des laboratoires publics ou privés. 


\section{Antioxidant plant metabolites affect leaching of mineral elements from}

\section{Callovo-Oxfordian clays}

D. UBERSFELD ${ }^{\mathrm{ab}}$, C. LEYVAL $^{\mathrm{ab}}$, P.O. REDON ${ }^{\mathrm{c}}$ \& C. MUSTIN ${ }^{\mathrm{ab}}$

${ }^{\mathrm{a} U n i v e r s i t e ́ ~ d e ~ L o r r a i n e, ~ L I E C, ~ F a c u l t y ~ o f ~ S c i e n c e s ~ a n d ~ T e c h n o l o g y, ~ B P ~ 70239, ~} 54506$ Vandoeuvre-les-Nancy Cedex, France, ${ }^{b}$ CNRS, LIEC, Faculty of Sciences and Technology,

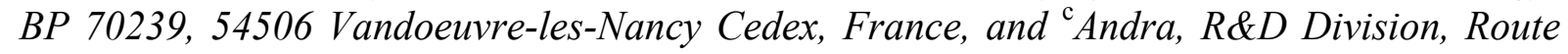
départementale 960 - BP 9, 55290 Bure, France.

Correspondence: C. Leyval. Email: corinne.leyval@univ-lorraine.fr

Running title: Antioxidants affect element leaching from clay 


\section{Summary}

Minerals excavated during industrial activities are stored on the soil surface, exposed to weathering, which leads to the initial development of soil. Plants contribute to soil mineral weathering, mainly by producing acidic or complexing root exudates. In addition, many plants produce antioxidant compounds and phenolic substances that could also contribute to mineral transformation processes, but have rarely been considered in relation to mineral weathering. An incubation experiment was carried out for two months under controlled conditions to assess the effects of antioxidant plant metabolites on the weathering processes of a clay mineral. A freshly excavated, sulphur-rich Callovo-Oxfordian argillite (COx) sample was artificially leached with three concentrations of three antioxidant compounds (linalool, thymol and carvacrol) or water as a control. The weathering of COx was followed by the analysis of amounts of anions and cations in the leachates. Chlorine, sulphate, nitrate, phosphate, calcium, magnesium and potassium were found in the leachates, whereas iron and aluminium were close to the detection limits. Sulphate leaching reflected the oxidation of the pyritic matter contained in COx (mainly fine pyrite particles) by air. Water alone was enough to cause notable leaching of elements such as $\mathrm{S}$ and $\mathrm{P}$, but the percentage of leached sulphate increased in the presence of two antioxidant compounds, carvacrol and thymol, and increased to $38 \%$ with thymol at $2 \mathrm{mg}^{-1}$ compared to the antioxidant-free control. Thus, antioxidant compounds could contribute to the leaching of elements from COx, depending on their nature and concentration.

Key words: argillite, alteration sulphide, thymol 


\section{Highlights}

- We assessed the effects of leaching with antioxidant plant metabolites on COx clay weathering

- Sulphate leaching reflected the oxidation of pyritic matter (mainly fine pyrite particles) by air

- Percentage of sulphate leaching increased to $38 \%$ with thymol at $2 \mathrm{mg} \mathrm{l}^{-1}$

- Antioxidant compounds contribute to the leaching of elements from $\mathrm{COx}$

\section{Introduction}

The construction of a deep geological waste repository in Meuse-Haute Marne, France (Andra, 2005) will lead to the excavation and long-term surface disposal of clayey bedrocks, i.e. Callovian-Oxfordian argillite (COx) (Lerouge et al., 2011). Throughout the construction process, and once the site is operational, stored excavated raw material will be exposed to wet and oxidizing surface conditions that are markedly different from those found in deep rock formations. Climatic and physicochemical changes (e.g. wet-dry periods, water run-off) and also biological factors (plant and microorganism activities) might contribute to COx weathering (Hirsch et al., 1995; Denef et al., 2002). This could lead to the leaching of compounds to groundwater, and also to the initial development of soil from the excavated raw material (Scholtus et al., 2015). A vegetation cover might be considered to limit erosion and element leaching.

Chemical and biological processes could be involved in COx weathering and lead to the leaching and mobility of elements under long-term disposal conditions. The COx commonly consists of a mixture of various reactive minerals such as aluminosilicates (illite and smectite), carbonates (siderite, dolomite), sulphides (pyrite) and iron oxi-hydroxides. According to previous studies, oxidation of submicrometric and fine pyrite grains is the first 
step of COx weathering (Charpentier et al., 2001). This acidifying oxidation of sulphide minerals is favourable to carbonate or phyllosilicate dissolution (Hersman et al., 1995). Anions (e.g. sulphates) and cations released in pore water can precipitate to form secondary minerals such as gypsum, jarosite, celestine and goethite (Charpentier et al., 2001; Gaucher et al., 2004). Moreover, organic complexing agents (e.g. EDTA) or low-molecular-weight organic acids (e.g. oxalic acid) modify mineral weathering and nutrient mobilization (Scholtus et al., 2009). Bio-produced or excreted metabolites such as protons, organic acids, quinones or siderophores modify $\mathrm{pH}$ and redox potential and promote element mobility (Hinsinger, 1998; Marschner, 2012). Conversely, aromatic or terpenic substances such as humic acids or essential oils produced by plants (thymol) might limit sulphide oxidation and acidification processes by decreasing the electrochemical reactivity of mineral surfaces (Mustin et al., 1992; Meline et al., 1996; Perdicakis et al., 2001).

Biological activity from plants and microorganisms can accelerate element release from mineral lattices and affect the availability of limiting nutrients such as iron, sulphur and phosphorus (Balland et al., 2010; Ferret et al., 2014). In COx, because of little water activity and limitations in nutrient and energy sources, bacteria usually occur in very low densities, less than $10^{3}$ cells $\mathrm{g}^{-1}$ (Poulain et al., 2008). However, microorganism density can increase rapidly when $\mathrm{COx}$ is exposed to surface conditions. In this context, the colonization of $\mathrm{COx}$ by plants could be the main biological factor in mineral weathering and also provide nutrients, water and carbon sources able to stimulate microbial activity.

Many plants produce phenolic and terpenic substances that have antioxidant properties (Anthony et al. 2012) and whose potential role in mineral transformation processes has never been investigated. Among those plants, Lamiaceae are hardy plants able to tolerate cold temperatures, salt stress and drought (Zollinger et al., 2007). They have been used to reduce soil erosion (Durán Zuazo et al., 2008) and could be considered as a vegetation cover for 
excavated COx heaps. A few publications have shown that pyrite oxidation was reduced in the presence of thymol (Mustin et al., 1992; Meline et al., 1996; Perdicakis et al., 2001). However, there is a general lack of knowledge on the effects of antioxidants on mineral weathering. Furthermore, there is no specific information on the effect of antioxidants on COx weathering.

We hypothesized that plant-produced antioxidant compounds might modify considerably the chemistry of the water that leaches from this sulphur-rich clay stone, mainly its sulphate content resulting from the oxidation of pristine pyritic matter. To test this hypothesis, we assessed the effect of water and the addition of antioxidants on mineral element leaching from COx. In a microcosm experiment carried out for 2 months in laboratory conditions, freshly excavated COx was artificially leached with three concentrations of linalool, thymol and carvacrol, or water as a control. These three compounds are among the most abundant antioxidant molecules produced by Lamiaceae plants (Anthony et al., 2012); they were selected for their well-known antioxidant properties (Ložienè \& Venskutonis, 2005; Lee et al., 2005). The weathering of COx under wet and dry alternating conditions was assessed by measuring changes in the anions, cations and $\mathrm{pH}$ of the leachates.

\section{Materials and methods}

The experimental device was designed to study the weathering of a COx sample through successive water leaching events after the addition of antioxidants. A fine layer of COx was used to reflect in situ physicochemical conditions that occur on a surface heap of the material. The first step of the experiment involved adding an antioxidant solution or water (control) to the COx sample for 24 hours and collecting the leachates. Then, the samples were leached 
with deionized water for 2 hours once a week for 57 days. The $\mathrm{pH}$ and the anion and cation concentrations in the leachates were measured to monitor mineral weathering.

\section{Clay samples}

We used COx excavated in June 2013 from the Andra Underground Research Laboratory (URL), which investigates radioactive waste disposal in deep COx formations (Andra, 2005) at Bure (France). The material was excavated from a 450-m deep Callovo-Oxfordian layer (50-100 million years). Immediately after excavation, the COx sample of 10-cm-sized blocks was transported to the laboratory, kept in dry conditions and at constant room temperature to limit any changes before the experiment. The mineralogy and geochemistry of COx have been extensively documented (Gaucher et al., 2004); they depend on depth, with changes in carbonate and clay contents (Table 1). The mean composition of our sample was $40 \%$ clay (mainly interstratified illite-smectite), $20 \%$ quartz, $30 \%$ carbonate (mainly calcite), $5 \%$ feldspar, less than $2 \%$ pyrite and $2 \%$ immature organic materials. The COx was ground and sieved to keep the 2- to 3-mm fraction and avoid fine clay particles, and it was not sterilized. Preliminary microbial analyses (culturable cell counting and DNA extraction) showed no detectable microbial community (data not shown).

\section{Antioxidant solutions}

We selected three antioxidant compounds: linalool (154 $\mathrm{g} \mathrm{mol}^{-1}$, ref: 101220791, SigmaAldrich, St Quentin Fallavier, France), carvacrol (150 g mol${ }^{-1}$, ref: 101247500, SigmaAldrich) and thymol (150 g mol ${ }^{-1}$, ref: 16254, Sigma-Aldrich). There were few data available on the relevant soil concentrations of these antioxidants, whereas in Lamiaceae (e.g. lavender, thyme) the concentration was around $20 \mathrm{mg} \mathrm{g}^{-1}$ fresh flower or leaf (Tsuro et al., 2001; Nielsen et al., 2015). According to the experimental setup described below, we used 
concentrations that were 10 to 100 times less than those in these plants. For each compound, three solutions ( $\mathrm{pH}$ 6.5) were prepared at concentrations of 2, 40 and $80 \mathrm{mg} \mathrm{l}^{-1}$ diluted in deionized water for immediate use. Meline et al. (1996) found an inhibitory effect of thymol on pyrite oxidation at $80 \mathrm{mg} \mathrm{l}^{-1}$.

\section{Experimental set-up}

We designed experimental devices (Figure 1) that consisted of column-like units based on a sterile vacuum filtration system (acetate cellulose filter, pore size $0.45 \mu \mathrm{m}$, Nalgene ${ }^{\circledR}$ ref: 734-5064, VWR, Fontenay-sous-Bois, France) equipped with a 250-ml upper receiver. A supplementary glass fibre pre-filter (pore size $1.5 \mu \mathrm{m}$ ) covered the filtration membrane to prevent clogging by clay particles. An aseptic glass bottle $(150 \mathrm{ml})$ was placed under the filtration system to collect leachates. To simulate a COx heap surface in situ, the upper receivers were filled with a single 5-mm thick layer of clay material $(10 \mathrm{~g})$. Two leaching steps were set up: (i) imbibition of COx with antioxidant solutions (first step, S1), and (ii) successive water imbibition and leaching periods (step two, S2). In the first step, COx was leached with $200 \mathrm{ml}$ of each antioxidant solution (linalool, thymol or carvacrol at 2, 40 or 80 $\mathrm{mg} \mathrm{l}^{-1}$ ), or deionized water for the controls. After 24 hours the filtered leachates were collected in the vials (first step, S1). Each COx-layered sample was then watered weekly with $50 \mathrm{ml}$ of deionized water (S2) and after 2 hours of contact, leachates were collected with a vacuum pump for thirty minutes. Between two successive S2 periods (7 days), COx was left to dry to simulate weather variation. Evaporation was estimated from the loss of weight in the receiver. The cumulative quantities of water absorbed by COx were calculated as the gains in weight after leaching and filtration. The leaching experiment included three replicates for each concentration, therefore a total of 30 experimental units. The experimental devices were 
kept in a controlled chamber for 57 days to induce imbibition-desiccation cycles (40\% hygrometry, $18^{\circ} \mathrm{C}$ (night) and $23^{\circ} \mathrm{C}$ (day) temperatures).

\section{Chemical analyses}

Prior to chemical analyses, the $\mathrm{pH}$ of the leachates was measured under an aseptic sterile atmosphere (Meterlab PHM250, Brønshøj, Denmark) before filtration at $0.22 \mu \mathrm{m}$ and storage in a dark room at $4^{\circ} \mathrm{C}$. Sulphate, chloride, phosphate and nitrate concentrations were measured on a Dionex ICS-3000 ion chromatography system (Thermo Scientific, Sunnyvale, CA, USA). Isocratic separations of $\mathrm{Cl}^{-}, \mathrm{NO}_{3}^{-}, \mathrm{SO}_{4}^{--}$and $\mathrm{PO}_{4}^{---}$were carried out with a polymeric surface-sulfonated analytical column (AS20, $4 \mathrm{~mm} \times 50 \mathrm{~mm})$ and a conductivity detector. A reagent-free eluent generator (EGC II-KOH cartridge, Dionex, Sunnyvale, CA, USA) was used to generate a potassium hydroxide eluent gradient at a rate of flow of $1 \mathrm{ml}$ minute $^{-1}$. The IC system was fitted with a $25-\mu 1$ loop and an autosampler for sample processing. The system control and post-run analyses were performed with Chromeleon ${ }^{\circledR}$ software (version 6.80, Dionex, Sunnyvale, CA, USA). The quantification limit for all analyses was $50 \mu \mathrm{g}^{-1}$ with $60 \%$ uncertainty according to the NF T 90-210 norm. Calcium, potassium, magnesium, sodium, aluminium, arsenic, strontium and iron were measured by inductively coupled plasma atomic emission spectrometry (ICP-AES) using a Varian 720 ES model. All samples were analysed with certified reference materials (stream sediments NCSDS 36006 and NCSDS 36004).

\section{Data analysis}

To study the volume-dependent leaching of anion species from our COx samples, a first-order kinetic model was used from the leaching step (S2). This model proceeds at a rate that 
depends linearly on the amount of a given element. The differential equation describing firstorder kinetics is as follows:

$$
r=\mathrm{d}\left(Q_{\mathrm{M}}\right) / \mathrm{dV}=-k\left(Q_{\mathrm{M}}\right)
$$

where $Q_{\mathrm{M}}$ is the amount of element leached ( $\mu \mathrm{M}$ per gram of COx claystone), $V$ is the reaction volume, i.e. the percolated volume $(\mathrm{ml}), r$ the rate of reaction $\left(\mathrm{nmol} \mathrm{g}^{-1} \mathrm{ml}^{-1}\right)$ and $k$ the first-order rate constant. The cumulative amount of inorganic species as a function of volume were characterized by the following exponential first-order equation:

$$
Q_{\mathrm{M}}=Q_{\max }\left(1-e^{-k V}\right)
$$

where $Q_{\max }$ is the maximum leachable quantity of elements. The $Q_{\max }$ corresponds to an asymptotic value of $Q_{\mathrm{M}}$ for an infinite cumulative volume, and depends on the total quantity and availability of each element in COx. We assumed that the rates of leaching were directly proportional to the amounts available in COx. Leaching rate constants $(k)$ and maximum values $\left(Q_{\max }\right)$ were estimated for chloride, nitrate, sulphate and phosphate (Figure 2). They were not estimated for cations because many of them (Al, Fe, Si) were close to the detection limits.

Normality of residuals and homogeneity of variance were tested using the Shapiro-Wilk's and Levine tests, respectively. Comparisons among treatments (antioxidants, concentrations, and the interactions between these two factors) for each variable were made with a two-way analysis of variance (ANOVA) followed by Fisher's least significant difference (LSD) test at the significance level $P=0.05$. Because we had an unbalanced dataset, the type II sum of squares were used for factors with non-significant interactions. However, for factors with significant interactions, type I sum of squares were used. For percentage data, values were arcsine-transformed before statistical analysis. We used XLStat Software (version 2012.6.01, Addinsoft, Paris, France) for data processing. 


\section{Results}

Water absorption by COx was larger at step S1 than at S2 (Figure 3), underlying the two leaching phases. From day 2 to day 30, no significant difference in the quantity of absorbed water was noted between the antioxidant-amended and control columns. Cracks caused by COx drying and swelling were observed during exposure to alternating dry and wet conditions (Figure 1). They spread following the drying-wetting cycles.

Regardless of the antioxidant input, $\mathrm{pH}$ values decreased slightly from 6.6 to 6.2 (average values) during step S1 (Figure 4). From day 2 until the end of the experiment (step S2) and regardless of the antioxidant-amended or control treatments, the leachate $\mathrm{pH}$ increased significantly from 6.2 to 7.1 , but remained below the expected equilibrium $\mathrm{pH}$ of 8.7 (Table 1). On day 57, no significant difference was noted between the control and amended COx leachates, regardless of the antioxidant and its concentration.

We analysed the leaching of chloride, nitrate, sulphate and phosphate from the COx sample. The data were fitted well by first-order kinetic models, and the coefficients of determination $\left(R^{2}\right)$ were close to 0.99 , except for phosphorus $(0.96)$. The sums of squares of deviations were close to 0 (Table 2). Subsequently, leached and cumulated quantities $(Q)$ of chloride, nitrate, sulphate and phosphate were estimated correctly by the models over the entire desiccationimbibition cycle. The first-order kinetic model enabled us to determine two parameters: the rate of reaction $k\left(\mathrm{nmol} \mathrm{g}^{-1} \mathrm{ml}^{-1}\right)$ and the maximum anion concentration $Q_{\max }\left(\mu \mathrm{mol} \mathrm{g}{ }^{-1}\right)$.

Among the four elements, the rate of leaching of chloride was the largest, but was not affected by addition of the antioxidants, in contrast to those of sulphate, nitrate and phosphate. Rates of leaching of chloride did not differ significantly between the control COx and the different treatments and concentrations, and were larger than those of sulphate, nitrate and phosphate (Figure 5). The rate of leaching of sulphate from thymol-treated COx was significantly less than in the control, but only when thymol was at a concentration of $2 \mathrm{mg}^{-1}(P=0.013)$. The 
rates of nitrate leaching of the samples treated with thymol and carvacrol at 2, 40 and $80 \mathrm{mg} \mathrm{l}^{-}$ ${ }^{1}(P<0.0002$ in all cases $)$, and linalool at 40 and $80 \mathrm{mg}^{-1}(P=0.001$ in both cases $)$ were larger than in the controls. The rate of phosphate leaching was significantly larger than for the control when thymol was at a concentration of $40 \mathrm{mg}^{-1}$ only $(P=0.035)$, and was larger in the presence of thymol than in the presence of linalool or carvacrol $(P \leq 0.017)$.

The maximum leachable element quantity $\left(Q_{\max }\right)$ was estimated for step $\mathrm{S} 2$. Nitrate $Q_{\max }$ values decreased with the addition of antioxidants, whereas those of chloride, sulphate and phosphate increased when thymol and linalool were added at certain concentrations. Chloride $Q_{\max }$ values were significantly larger in the presence of linalool at $2 \mathrm{mg} \mathrm{l}^{-1}$ and thymol at 80 $\mathrm{mg}^{-1}$ than in the control $(P=0.034$ and 0.001$)$ (Figure 6). By contrast, in relation to the rate of nitrate leaching (Figure 5) large concentrations of linalool and thymol (40 and $80 \mathrm{mg} \mathrm{l}^{-1}$, respectively) decreased $Q_{\max }$ compared to the control $(P \leq 0.013$ for linalool and $\leq 0.003$ for thymol). A similar trend was noted with carvacrol, regardless of the antioxidant concentration $(P<0.003)$. Sulphate and phosphate $Q_{\max }$ values increased significantly in the presence of thymol at $2 \mathrm{mg} \mathrm{l}^{-1}$ compared to the control $(P \leq 0.0002)$. Both sulphate and phosphate $Q_{\max }$ values differed significantly depending on the antioxidant concentrations $(P \leq 0.001)$.

To quantify the initial COx elements leached during the experiment, the quantity of elements leached in steps S1 and S2 was related to the initial COx content. There was a greater percentage of sulphur $\left(7.1 \%\right.$, equivalent to $\left.18.42 \mu \mathrm{mol} \mathrm{g}^{-1} \mathrm{COx}\right)$ than phosphorus $(0.04 \%$, equivalent to $0.0036 \mu \mathrm{mol} \mathrm{g}{ }^{-1} \mathrm{COx}$ ) leached from COx in the first leaching step (S1), but then the opposite was observed during the following successive leaching periods from 9 to 57 days (S2), with $2.4 \%$ of sulphur (equivalent to $6.14 \mu \mathrm{mol} \mathrm{g}{ }^{-1} \mathrm{COx}$ ) and $4.9 \%$ of phosphorus (equivalent to $0.40 \mu \mathrm{mol} \mathrm{g}{ }^{-1} \mathrm{COx}$ ). Thymol and to a lesser extent carvacrol increased the leaching percentages of S and P compared to the control. In step 1, the percentages of leached $\mathrm{S}$ increased significantly in the presence of thymol at $2 \mathrm{mg}^{-1}$ (Table 3) compared to the 
control $(P=0.004)$. The percentage of leached $\mathrm{P}$ also increased significantly in the presence of thymol at $40 \mathrm{mg} \mathrm{l}^{-1}(P=0.004)$. In step 2 , thymol at $2 \mathrm{mg} \mathrm{l}^{-1}$ increased the percentages of leached $\mathrm{S}$ and $\mathrm{P}$ compared to the control $(P<0.0002)$. The two-way ANOVA for steps $\mathrm{S} 1$ and S2 showed that the leaching of $\mathrm{P}$ differed with the antioxidant $(P=0.003$ and 0.001$)$, and thymol led to the greatest percentage of leaching.

We analysed cations in the leachates: potassium, calcium and magnesium were found in step 1, whereas iron and aluminium were close to the detection limits $\left(<5 \mu \mathrm{g}^{-1}\right)$. Regardless of the antioxidant concentrations, potassium leaching tended to be less in the leachates from thymol-treated $\left(8.1 \mu \mathrm{mol} \mathrm{g}{ }^{-1} \mathrm{COx}\right.$, representing $2.0 \%$ of the initial content) and linalooltreated $\left(7.5 \mu \mathrm{mol} \mathrm{g} \mathrm{g}^{-1} \mathrm{COx}, 1.8 \%\right) \mathrm{COx}$ than the control $\left(8.8 \mu \mathrm{mol} \mathrm{g} \mathrm{g}^{-1} \mathrm{COx}, 2.1 \%\right)$. Regardless of the antioxidant concentration, calcium and magnesium leaching were similar in the leachates from linalool-treated (4.84 and $2.47 \mu \mathrm{mol} \mathrm{g}^{-1} \mathrm{COx}, 0.2 \%$ and $0.2 \%$ of the initial content, respectively) and carvacrol-treated COx (3.96 and $2.15 \mu \mathrm{mol} \mathrm{g} \mathrm{g}^{-1} \mathrm{COx}, 0.1 \%$ and 0.2 $\%$, respectively) to the control (3.97 and $1.9 \mu \mathrm{mol} \mathrm{g}^{-1} \mathrm{COx}, 0.1 \%$ and $0.2 \%$, respectively). Calcium and magnesium contents in the leachates from COx treated with thymol at $2 \mathrm{mg}^{-1}$ (5.61 and $2.63 \mu \mathrm{mol} \mathrm{g}^{-1} \mathrm{COx}, 0.2 \%$ and $0.3 \%$, respectively) were slightly larger than in the control (3.97 and $1.91 \mu \mathrm{mol} \mathrm{g}{ }^{-1} \mathrm{COx}, 0.1 \%$ and $0.2 \%$, respectively).

\section{Discussion}

\section{Element leaching from $\mathrm{COx}$}

This first imbibition of the anhydrous and freshly excavated COx, corresponding to antioxidant input, the slight decrease in $\mathrm{pH}$ and the large amounts of sulphate in the leachates ( 6 to $8 \%$ ) could be explained by the dissolution of oxidized species formed previously during the initial alteration of COx. They might originate from pore water, sulphide mineral 
weathering (pyrite, celestite) or be complexed by organic matter (Gaucher et al., 2004). Acidity as a result of pyrite and sulphide alteration has been reported (Gleisner \& Herbert, 2002). The first wetting-drying cycle might have decreased mineral aggregation and enhanced the turnover of mineral aggregates (Denef et al., 2001). This initial element leaching might be explained by clay layer spacing when anhydrous COx was leached with deionized water or the antioxidant solutions. Chlorine, sulphate, phosphate and nitrate present in the leachates came from pore water. The alkalinity of the leachates was moderate, as shown by the potassium $(0.32 \mathrm{mM})$, calcium $(0.15 \mathrm{mM})$ and magnesium $(0.10 \mathrm{mM})$ concentrations. Scholtus et al. (2009) performed a column leaching experiment with anhydrous and freshly excavated $\mathrm{COx}$ with $\mathrm{KCl}$ equilibration. They found potassium (4 mM), calcium (7 $\mathrm{mM})$, magnesium $(5 \mathrm{mM})$ and small amounts of aluminium and iron $(<0.2 \mu \mathrm{M})$ in the leachates. This accords with the pore water chemistry model of COx proposed by Gaucher et al. (2004). The model suggested that the equilibrium concentrations of $\mathrm{Fe}, \mathrm{Si}$ and $\mathrm{Al}$ in water were between three to four orders of magnitude less than the equilibrium concentration of sulphate. The small availability of $\mathrm{Al}$ and $\mathrm{Fe}\left(<5 \mu \mathrm{g} \mathrm{kg}^{-1}\right)$ might result from the buffering capacity of COx and adsorption on cation exchange sites on the clay material (Golubev et al., 2006), which is similar to our results. Because of the moderate alkalinity of leachates, the availability of multivalent metal cations $(\mathrm{Fe}, \mathrm{Al}, \mathrm{Ca})$ is determined by the equilibrium with carbonates (e.g. siderite, calcite). Thus, the iron and aluminium contents of the COx leachates were quite small. Therefore the analyses were focused mainly on anions, such as sulphates.

During the second step corresponding to weekly water leaching, changes in $\mathrm{pH}$ and the anion dissolution kinetics characterized COx oxidation and leaching processes. The increase in $\mathrm{pH}$ value from 6.2 to 7.1 was consistent with the study of Elie et al. (2004), who reported pH values increasing from 5.5 to 7.5 when non-oxidized $\mathrm{COx}$ was leached with deionized water. The $\mathrm{pH}$ of leachates from $\mathrm{COx}$ also increased with the addition of $\mathrm{KCl}$ solutions (Scholtus et 
al. 2009). These authors explained that the increased $\mathrm{pH}$ resulted from the buffering capacity of calcite and COx mineral weathering. Thus, a major leaching process may occur quickly after excavation of COx. Element losses reached $8 \%$ of total sulphur and around $3 \%$ of total phosphorus with smaller percentages for $\mathrm{Ca}$, and $\mathrm{Mg}(0.2-0.3 \%)$ in our study. Element loss phenomena are related to the initial leaching of residual seawater salt from $\mathrm{COx}$ and to ion exchanges during the leaching processes.

\section{Weathering of COx is controlled by the oxidation of pyrite grains}

The rapid leaching of sulphates from COx confirmed that the first step in COx weathering was controlled by the oxidation of pyrite grains dispersed in the clay matrix (Charpentier et al., 2001). Elements such as $\mathrm{Si}, \mathrm{Fe}$ and $\mathrm{Al}$ were released in the leachates in very small quantities during the short-time leaching experiment. The iron contents were also quite small and were controlled by the equilibrium with siderite, which has been found in COx (Gaucher et al., 2004). In anoxic, deep ground conditions, sulphides act as a redox sink for sulphur and iron. Conversely, under oxic conditions encountered during excavation or crushing processes, atmospheric-oxidation of the small-sized pyrite particles of COx occurs rapidly and causes the formation of several intermediate ions and acidic secondary products. The variation in $\mathrm{pH}$ probably arose from acidification resulting from both pyrite oxidation and precipitation of ferric hydroxide and buffering by carbonates. According to Equation (3), pyrite oxidation by oxygen leads to the release of four moles of protons per mole of oxidized pyrite (Lowson, 1982). Acidification is enhanced by the oxidation of both $\mathrm{Fe}(\mathrm{II})$ and disulphides(-II):

$2 \mathrm{FeS}_{2}+{ }^{15} / 2 \mathrm{O}_{2}+7 \mathrm{H}_{2} \mathrm{O}$-> $2 \mathrm{Fe}(\mathrm{OH})_{3}+4 \mathrm{SO}_{4}{ }^{--}+8 \mathrm{H}^{+}$.

The bulk mineralogy of our COx sample provided a good buffering capacity, especially with the presence of silicates and reactive carbonates, mainly calcite (Table 1), therefore, acidification from pyrite and sulphide oxidation was not detectable (Gleisner \& Herbert, 
2002). Because of the lower solubility of Fe(III), the electrochemical, autocatalytic and rapid oxidation of pyrite did not occur.

In the present study, which was done at a neutral $\mathrm{pH}$, pyrite oxidation occurred first by chemical oxidation of sulphur(II) and iron(II) by atmospheric oxygen and water-dissolved oxygen. Moses \& Herman (1991) suggested an electrochemical mechanism for pyrite oxidation at circumneutral $\mathrm{pH}$ values that involves adsorbed $\mathrm{Fe}(\mathrm{II})$. Adsorbed $\mathrm{Fe}(\mathrm{II})$ gives up electrons to dissolved oxygen, and the resulting $\mathrm{Fe}(\mathrm{III})$ is rapidly reduced by sulphide. Because of successive additions of dissolved oxygen by imbibition, the oxidative cycle of adsorbed iron occurs, and sulphoxy species and protons are generated from the pyrite surface. Thus, the rate of sulphate accumulation in the leachate $(k)$ and acidification are implicitly proportional to the rate of pyrite oxidation and to the reactive surface of pyritic matter. This electrochemical cycle plays an important role in COx alteration and might depend on ferric oxidation by atmospheric oxygen (Torma \& Bosecker, 1982).

\section{Effect of antioxidants}

Our results show that the effect of antioxidants on element leaching from COx depends on the nature and concentration of antioxidants. Although the three antioxidants increased the rate of nitrate leaching and decreased nitrate $Q_{\max }$ compared to the control, significant effects on the leaching of S and P were observed mainly in the presence of thymol. The difference between antioxidants was not related to different degrees of solubility in water because the solubility of thymol $\left(1 \mathrm{~g} \mathrm{l}^{-1}\right)$ was less than that of the other two compounds $\left(1.56 \mathrm{~g}^{-1}\right.$ for linalool and $1.25 \mathrm{~g}^{-1}$ for carvacrol). Carvacrol and thymol are isomeric compounds that differ mainly by the position of the hydroxyl group (Lee et al., 2005). The position of the hydroxyl functional group might have contributed to the different results observed in the presence of carvacrol and thymol. According to Hui et al. (2017), such a difference explained the larger inhibition of 
bacterial synthesis or activity by carvacrol in comparison with thymol. The differences we noted between antioxidant nature and concentrations might be explained by differential antioxidant adsorption on COx. Although the antioxidant hydrophobicity values were almost equivalent (log Kow (n-octanol/water partition coefficient) with values of 3.3 for thymol, 3.5 for carvacrol and linalool (Griffin et al., 1999), sorption and desorption experiments would be useful to ascertain such differences, but are difficult to do because of analytical limitations. Linalool is an acyclic monoterpene, whereas thymol and carvacrol are monocyclic monoterpenes (Degenhardt et al., 2009). These structural differences might affect the adsorption and volatility of these compounds on mineral surfaces.

The effect of antioxidants on element leaching from $\mathrm{COx}$ was not proportional to their concentrations. Thymol decreased significantly the rate of sulphate leaching, but increased the sulphate $Q_{\max }$ and leaching percentage compared to the control. However, these significant effects were noted at the smallest antioxidant concentration only $\left(2 \mathrm{mg} \mathrm{l}^{-1}\right)$. According to Meline et al. (1996) the inhibition of pyrite oxidation by $2 \mathrm{mg}^{-1}$ of thymol was due to partial covering of pyrite active sites by thymol. The inhibition of pyrite oxidation through the formation of an oxidized thymol film complexed to ferric iron from the pyrite surface has also been reported (Perdicakis et al., 2001). At a larger antioxidant concentration, a greater surface covering would be expected. However, at a larger concentration of thymol or other antioxidant compounds, such as 40 or $80 \mathrm{mg} \mathrm{l}^{-1}$, a bactericidal effect might occur (Meline et $a l ., 1996)$ and interfere with or counteract the adsorption effect. In addition to being adsorbed, thymol at a small concentration could move into clay layer spacing, stabilize the clay structure and decrease the leaching of elements. However, antioxidant sorption on mineral surfaces can be reversed by washing. Brickett et al. (1995) showed a decrease in the abiotic rate of leaching of copper ore wetted with a thymol solution that disappeared after washing 
the ore. During the leaching step (S2), antioxidant adsorption might therefore have decreased because of leaching with water and thymol volatilization (Hu \& Coats, 2008) from pyrite surfaces (Meline et al., 1996).

Several studies have used organic acids or amino acids to simulate the effects of the rhizosphere physicochemical conditions on mineral weathering. Scholtus et al. (2009) studied COx weathering by adding low-molecular-weight organic compounds (oxalate, acetate, histidine, EDTA) and measuring cation leaching. In their experiment, organic ligands such as histidine or EDTA increased calcium $(>0.2 \mathrm{mM})$, magnesium $(>0.1 \mathrm{mM})$ and potassium $(>$ $0.2 \mathrm{mM}$ ) leaching, and small amounts of aluminium and iron (close to the detection limit) were detected from histidine-treated COx. To assess the effect of plant antioxidant compounds on COx weathering, they should be considered as well as other compounds from root exudates.

In our experiment, the addition of antioxidant increased alteration with $\mathrm{S}$ and $\mathrm{P}$ leaching, but only leaching processes were considered. Antioxidants might limit physicochemical and also biological mineral weathering (Mustin et al., 1992; Kraus et al., 2003). They can inhibit microbial activity and therefore microbial weathering (Meline et al., 1996). Organic matter associated with pyrite or inside clay layers is potentially an efficient organic substrate for microorganisms (Faure et al., 1999). Therefore, the effect of antioxidants on COx weathering could be investigated further under biotic conditions to include the indirect effect on microbemediated alteration.

\section{Conclusions}

Little information is available on plant antioxidant compounds in the soil and how such compounds might affect the weathering of minerals. Our hypothesis was that the antioxidant property of such compounds would limit the oxidation of sulphur-bearing minerals such as 
pyrite. However, the three biologically produced antioxidant compounds tested in this study did not reduce COx weathering throughout our short-term experiment. The leaching of elements was already considerable with water leaching. Within 24 hours, $7 \%$ sulphur, $0.2 \%$ calcium, $1.9 \%$ potassium and $0.2 \%$ magnesium had been leached, indicating that the excavated COx will evolve rapidly under rainy conditions. After 57 days, percentages of sulphate and phosphorus leached reached largher values of 8 and 3\%, respectively. However, the percentage of sulphate leached from COx increased to $38 \%$ in the presence of thymol at 2 $\mathrm{mg}^{-1}$ compared to the antioxidant-free control. Consequently, antioxidant compounds could contribute to the leaching of elements from $\mathrm{COx}$, but such an effect was not observed at larger concentrations of the antioxidants or with the other compounds. Such results could be explained by interactions between antioxidants and COx minerals (e.g. pyrite, organic matter, clay particles) and also biological activity depending on antioxidant concentration. The use of plants that produce antioxidant compounds to vegetate $\mathrm{COx}$ heaps might therefore contribute to the leaching of elements from it, but other effects of plants such as the prevention of erosion, root exudation of other compounds and mineral element uptake should also be considered.

\section{References}

Andra. 2005. Evaluation of the Feasibility of a Geological Repository in an Argillaceous Formation. Dossier 2005 Argile. Report Series. Available at http://www.andra.fr/international/pages/en/menu21/waste-management/research-anddevelopment/dossier-2005-1636.html. ANDRA Publications, Chatenay-Malabry, France

Anthony, K.P., Deolu-Sobogun, S.A. \& Saleh, M.A. 2012. Comprehensive assessment of antioxidant activity of essential oils. Journal of Food Science, 77, C839-C843. 
Balland, C., Poszwa, A., Leyval, C. \& Mustin, C. 2010. Dissolution rates of phyllosilicates as a function of bacterial metabolic diversity. Geochimica et Cosmochimica Acta, 74, 54785493.

Brickett, L.A., Hammack, R.W. \& Edenbom, H.M. 1995. Comparison of methods used to inhibit bacterial activity in sulfide ore bioleaching studies. Hydrometallurgy, 39, 293-305.

Charpentier, D., Cathelineau, M., Mosser-Ruck, R. \& Bruno, G. 2001. Évolution minéralogique des argilites en zone sous-saturée oxydée : exemple des parois du tunnel de Tournemire (Aveyron, France). Comptes Rendus de l'Académie des Sciences - Series IIA Earth and Planetary Science, 332, 601-607.

Degenhardt, J., Köllner, T.G. \& Gershenzon, J. 2009. Monoterpene and sesquiterpene synthases and the origin of terpene skeletal diversity in plants. Phytochemistry, 70, 16211637.

Denef, K., Six, J., Bossuyt, H., Frey, S.D., Elliott, E.T., Merckx, R. \& Paustian, K. 2001. Influence of dry-wet cycles on the interrelationship between aggregate, particulate organic matter, and microbial community dynamics. Soil Biology \& Biochemistry, 33, 1599-1611.

Denef, K., Six, J., Merckx, R. \& Paustian, K. 2002. Short-term effects of biological and physical forces on aggregate formation in soils with different clay mineralogy. Plant and Soil, 246, 185-200.

Durán Zuazo, V.H., Rodríguez Pleguezuelo, C.R., Francia Martínez, J.R., Cárceles Rodríguez, B., Martínez Raya, A. \& Pérez Galindo, P. 2008. Harvest intensity of aromatic shrubs vs. soil erosion: An equilibrium for sustainable agriculture (SE Spain). Catena, 73, $107-116$.

Elie, M., Faure, P., Michels, R., Landais, P., Griffault, L., Mansuy, L. \& Martinez, L. 2004. Effects of water-cement solutions on the composition of organic compounds leached from oxidized Callovo-Oxfordian argillaceous sediment. Applied Clay Science, 26, 309-323.

Faure, P., Landais, P. \& Griffault, L. 1999. Behavior of organic matter from Callovian shales during low-temperature air oxidation. Fuel, 78, 1515-1525. 
Ferret, C., Sterckeman, T., Cornu, J.-Y., Gangloff, S., Schalk, I.J. \& Geoffroy, V.A. 2014. Siderophore-promoted dissolution of smectite by fluorescent Pseudomonas. Environmental Microbiology Reports, 6, 459-467.

Gaucher, E., Robelin, C., Matray, J.M., Négrel, G., Gros, Y., Heitz, J.F. et al. 2004. ANDRA underground research laboratory: interpretation of the mineralogical and geochemical data acquired in the Callovian-Oxfordian formation by investigative drilling. Physics and Chemistry of the Earth, Parts $A / B / C, 29,55-77$.

Gleisner, M. \& Herbert, R.B. 2002. Sulfide mineral oxidation in freshly processed tailings: batch experiments. Journal of Geochemical Exploration, 76, 139-153.

Golubev, S.V., Bauer, A. \& Pokrovsky, O.S. 2006. Effect of $\mathrm{pH}$ and organic ligands on the kinetics of smectite dissolution at $25{ }^{\circ} \mathrm{C}$. Geochimica et Cosmochimica Acta, 70, 44364451.

Griffin, S., Wyllie, S.G. \& Markham, J. 1999. Determination of octanol-water partition coefficient for terpenoids using reversed-phase high-performance liquid chromatography. Journal of Chromatography A, 864, 221-228.

Hersman, L., Lloyd, T. \& Sposito, G. 1995. Siderophore-promoted dissolution of hematite. Geochimica Et Cosmochimica Acta, 59, 3327-3330.

Hinsinger, P. 1998. How do plant roots acquire mineral nutrients? Chemical processes involved in the rhizosphere. Advances in Agronomy, 64, 225-265.

Hirsch, P., Eckhardt, F.E.W. \& Palmer, R.J. 1995. Methods for the study of rock-inhabiting microorganisms-A mini review. Journal of Microbiological Methods, 23, 143-167.

Hu, D. \& Coats, J. 2008. Evaluation of the environmental fate of where science meets business thymol and phenethyl propionate in the laboratory. Pest Management Science, 64, $775-779$.

Hui, X., Yan, G., Tian, F.-L., Li, H. \& Gao, W.-Y. 2017. Antimicrobial mechanism of the major active essential oil compounds and their structure-activity relationship. Medicinal Chemistry Research, 26, 442-449. 
Kraus, T.E.C., Dahlgren, R.A. \& Zasoski, R.J. 2003. Tannins in nutrient dynamics of forest ecosystems-a review. Plant and Soil, 256, 41-66.

Lee, S.-J., Umano, K., Shibamoto, T. \& Lee, K.-G. 2005. Identification of volatile components in basil (Ocimum basilicum L.) and thyme leaves (Thymus vulgaris L.) and their antioxidant properties. Food Chemistry, 91, 131-137.

Lerouge, C., Grangeon, S., Gaucher, E.C., Tournassat, C., Agrinier, P., Guerrot, C. et al. 2011. Mineralogical and isotopic record of biotic and abiotic diagenesis of the CallovianOxfordian clayey formation of Bure (France). Geochimica et Cosmochimica Acta, 75, $2633-2663$.

Lowson, R.T. 1982. Aqueous oxidation of pyrite by molecular oxygen. Chemical Reviews, 82, 461-497.

Ložienė, K. \& Venskutonis, P.R. 2005. Influence of environmental and genetic factors on the stability of essential oil composition of Thymus pulegioides. Biochemical Systematics and Ecology, 33, 517-525.

Marschner, P. 2012. Marschner's Mineral Nutrition of Higher Plants. Third Edition. Academic Press, London.

Meline, F., Mustin, C. \& De Donato, P. 1996. Adsorption of thymol can limit bacterial oxidation of pyrite. Comptes Rendus De L'Academie Des Sciences Serie II, 322, 959-964.

Moses, C. \& Herman, J. 1991. Pyrite oxidation at circumneutral pH. Geochimica et Cosmochimica Acta, 55, 471-482.

Mustin, C., Berthelin, J., Marion, P. \& De Donato, P. 1992. Corrosion and electrochemical oxidation of a pyrite by Thiobacillus ferrooxidans. Applied and Environmental Microbiology, 58, 1175-1182.

Nielsen, J.A., Frew, R.D., Whigam, P.A., Callaway, R.M. \& Dickinson, K.J.M. 2015. Germination and growth responses of co-occurring grass species to soil from under invasive Thymus vulgaris. Allelopathy Journal, 35, 139-152. 
Perdicakis, M., Geoffroy, S., Grosselin, N. \& Bessière, J. 2001. Application of the scanning reference electrode technique to evidence the corrosion of a natural conducting mineral: pyrite. Inhibiting role of thymol. Electrochimica Acta, 47, 211-216.

Poulain, S., Sergeant, C., Simonoff, M., Le Marrec, C. \& Altmann, S. 2008. Microbial investigations in Opalinus Clay, an argillaceous formation under evaluation as a potential host rock for a radioactive waste repository. Geomicrobiology Journal, 25, 240-249.

Scholtus, N., Echevarria, G., Florentin, L., Bonis, M.-L., De Donato, P., Simonnot, M.-O. \& Morel, J.-L. 2015. Expected evolution of a Technosol derived from excavated CallovoOxfordian clay material. Journal of Soils and Sediments, 15, 332-346.

Scholtus, N., Leclerc, E., De Donato, P., Morel, J.L. \& Simonnot, M.O. 2009. Eluto-frontal chromatography to simulate chemical weathering of $\mathrm{COx}$ by low-molecular-weight organic compounds and early pedogenesis processes. European Journal of Soil Science, 60, 71-83.

Torma, A.E. \& Bosecker, K. 1982. Bacterial leaching. Progress in Industrial Microbiology, 16, 77-118.

Tsuro, M., Inoue, M. \& Kameoka, H. 2001. Variation in essential oil components in regenerated lavender (Lavandula vera DC) plants. Scientia Horticultura,e 88, 309-317.

Zollinger, N., Koenig, R., Cerny-Koenig, T. \& Kjelgren, R. 2007. Relative salinity tolerance of intermountain western United States native herbaceous perennials. Hortscience, 42, $529-534$.

\section{Table and figure legends}

Table 1 Chemical composition and reactivity of COx. Values are the means of 8 replicates. Granulometry was measured on the ground and 2- to 3-mm sieved sample. 


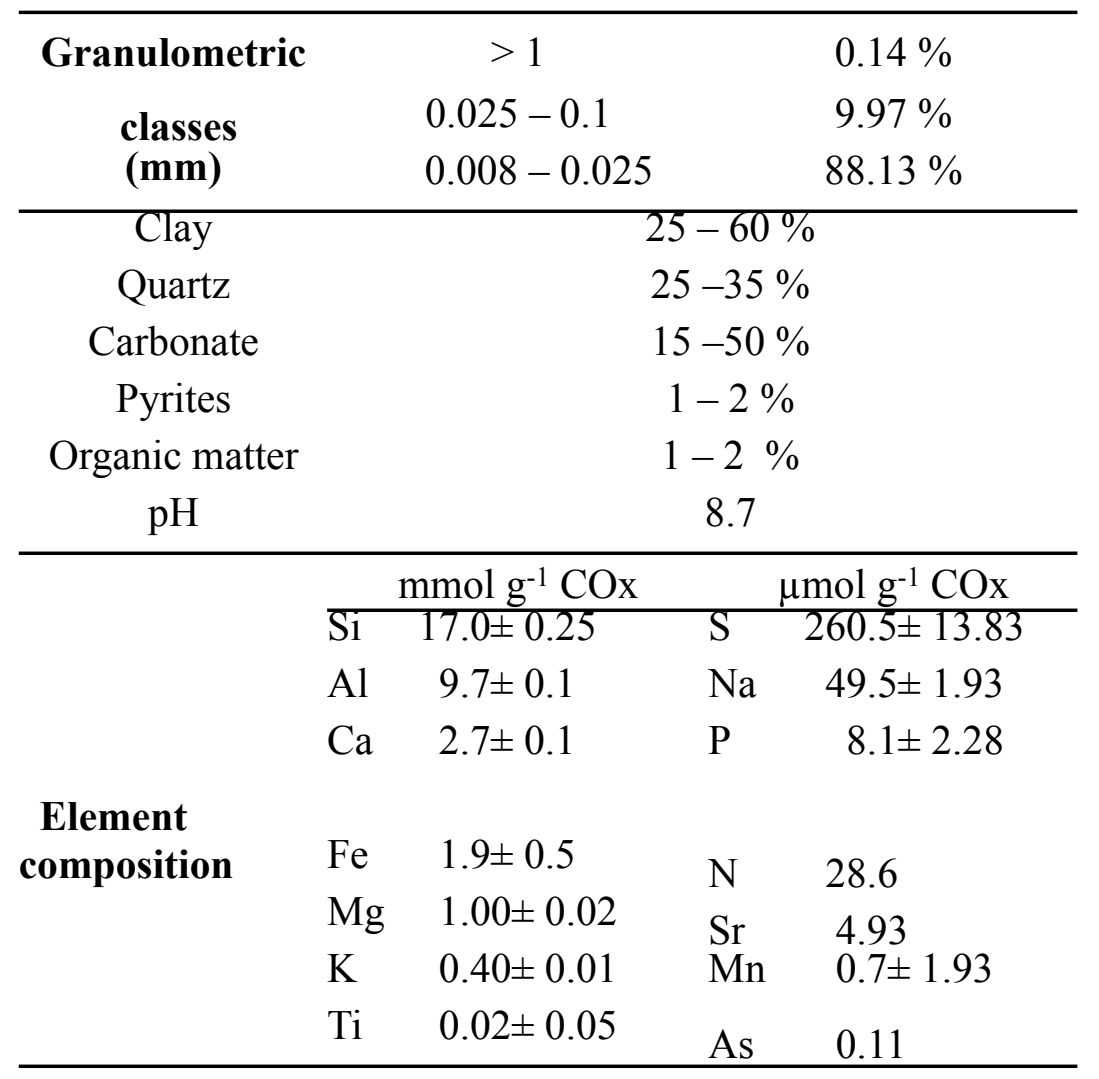

Table 2 Coefficients of determination $\left(R^{2}\right)$ and sums of squares of the deviations between the modelled and measured values of cumulated leached quantities of chloride $(\mathrm{Cl})$, nitrate $\left(\mathrm{NO}_{3}\right)$, sulphate $\left(\mathrm{SO}_{4}\right)$ and phosphate $\left(\mathrm{PO}_{4}\right)$ over time. 


\begin{tabular}{|c|c|c|c|c|c|c|c|c|c|}
\hline \multirow{3}{*}{ Modalities } & \multirow[b]{2}{*}{$\begin{array}{c}\text { Concentrati } \\
\text { ons }\end{array}$} & \multicolumn{4}{|c|}{ Coefficient of determination } & \multicolumn{4}{|c|}{ Sum of squares of deviations } \\
\hline & & $\mathrm{Cl}$ & $\mathrm{NO}_{3}$ & $\mathrm{SO}_{4}$ & $\mathrm{PO}_{4}$ & $\mathrm{Cl}$ & $\mathrm{NO}_{3}$ & $\mathrm{SO}_{4}$ & $\mathrm{PO}_{4}$ \\
\hline & 2 & 0.998 & 0.999 & 0.999 & 0.982 & 0.018 & 0.001 & 0.582 & 0.011 \\
\hline \multirow[t]{3}{*}{ Linalool } & 40 & 0.998 & 0.998 & 0.999 & 0.901 & 0.018 & 0.001 & 0.582 & 0.021 \\
\hline & 80 & 0.998 & 0.998 & 0.999 & 0.966 & 0.018 & 0.001 & 0.542 & 0.003 \\
\hline & 2 & 0.998 & 0.999 & 0.999 & 0.973 & 0.018 & 0.001 & 0.359 & 0.005 \\
\hline \multirow[t]{3}{*}{ Carvacrol } & 40 & 0.998 & 0.999 & 0.999 & 0.943 & 0.018 & 0.001 & 0.514 & 0.002 \\
\hline & 80 & 0.998 & 0.999 & 0.999 & 0.926 & 0.018 & 0.001 & 0.497 & 0.009 \\
\hline & 2 & 0.998 & 0.999 & 0.999 & 0.913 & 0.018 & 0.001 & 0.575 & 0.110 \\
\hline \multirow[t]{2}{*}{ Thymol } & 40 & 0.998 & 0.998 & 0.999 & 0.998 & 0.018 & 0.001 & 0.397 & 0.000 \\
\hline & 80 & 0.998 & 0.999 & 0.999 & 0.982 & 0.019 & 0.001 & 0.395 & 0.004 \\
\hline Control & 0 & 0.998 & 0.999 & 0.999 & 0.982 & 0.018 & 0.001 & 0.216 & 0.002 \\
\hline
\end{tabular}

Table 3 Percentages of sulphur and phosphorus (\%) leached from COx after 57 days of incubation compared to initial COx. Means \pm standard errors $(n=3)$. The percentage was calculated as the ratio of the cumulated quantity of element leached from $10 \mathrm{~g}$ of COx over the initial quantity of elements in COx. Results of the two-way ANOVA ( $F$ ratio and $P$ significance level) comparing antioxidant treatments and antioxidant concentrations are given in the table. D.f, degree of freedom. The type I sum of squares were used for phosphorus at steps S1 and S2 and sulphur at S2. The type II sum of squares wre used for sulphur at S1; standard errors were calculated from the residuals of the mean squares of the two-way ANOVA for each element at step S1 (transformed means (arcsin) \pm standard error):0.06965 \pm 0.00004 (sulphur) and 4.2E-04 $\pm 6.05 \mathrm{E}-08$ (phosphorus) and S $0.022881 \pm 0.000018$ (sulfur) and $0.04637 \pm 0.00023$ (phosphorus) COx initial composition: $260.5 \mu \mathrm{mol} \mathrm{S} \mathrm{g}{ }^{-1}$ COx and 8.1 $\mu \mathrm{mol} \mathrm{P} \mathrm{g}{ }^{-1} \mathrm{COx}$. 
Element leaching (\%)

S1 S2

\begin{tabular}{|c|c|c|c|c|c|}
\hline Antioxidants & Concentrations $\left(\mathrm{mg} \mathrm{l}^{-1}\right)$ & $\mathbf{S}$ & $\mathbf{P}$ & $S$ & $\mathbf{P}$ \\
\hline & 2 & 7.7 & 0.10 & 3.0 & 6.1 \\
\hline \multirow[t]{3}{*}{ Linalool } & 40 & 7.3 & 0.02 & 2.8 & 5.3 \\
\hline & 80 & 6.8 & 0.02 & 2.1 & 3.0 \\
\hline & 2 & 8.0 & 0.05 & 3.5 & 12.3 \\
\hline \multirow[t]{3}{*}{ Thymol } & 40 & 6.6 & 0.10 & 1.8 & 4.0 \\
\hline & 80 & 6.9 & 0.07 & 1.7 & 4.5 \\
\hline & 2 & 6.7 & 0.04 & 2.3 & 4.6 \\
\hline \multirow[t]{2}{*}{ Carvacrol } & 40 & 6.9 & 0.04 & 2.2 & 3.3 \\
\hline & 80 & 7.4 & 0.01 & 2.3 & 2.7 \\
\hline Control & 0 & 6.4 & 0.03 & 1.9 & 3.3 \\
\hline
\end{tabular}


Figure 1 Experimental set-up with inputs of antioxidant (thymol, linalool or carvacrol) treated water or deionized water (control). The small picture at the top shows a COx sample after a drying period in step S2.

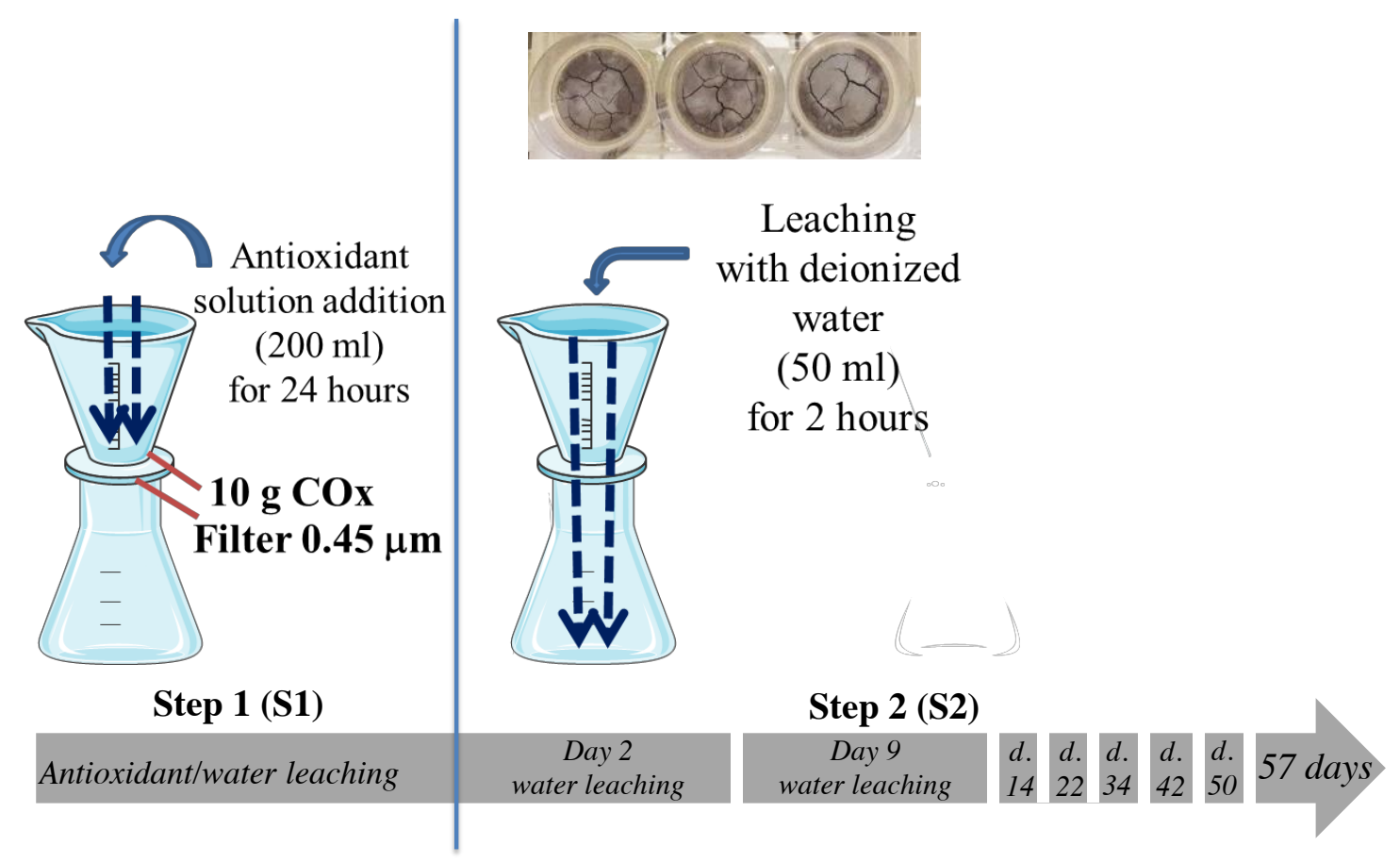


Figure 2 Cumulative quantities of $\mathrm{SO}_{4}\left(\mu \mathrm{mol} \mathrm{g}{ }^{-1} \mathrm{COx}\right)$ based on cumulated volumes $(\mathrm{ml})$. Blue circles, experimental data; continuous lines, first-order kinetic model curves for thymol at $2 \mathrm{mg} \mathrm{l}^{-1}$ and the control $(n=1)$.

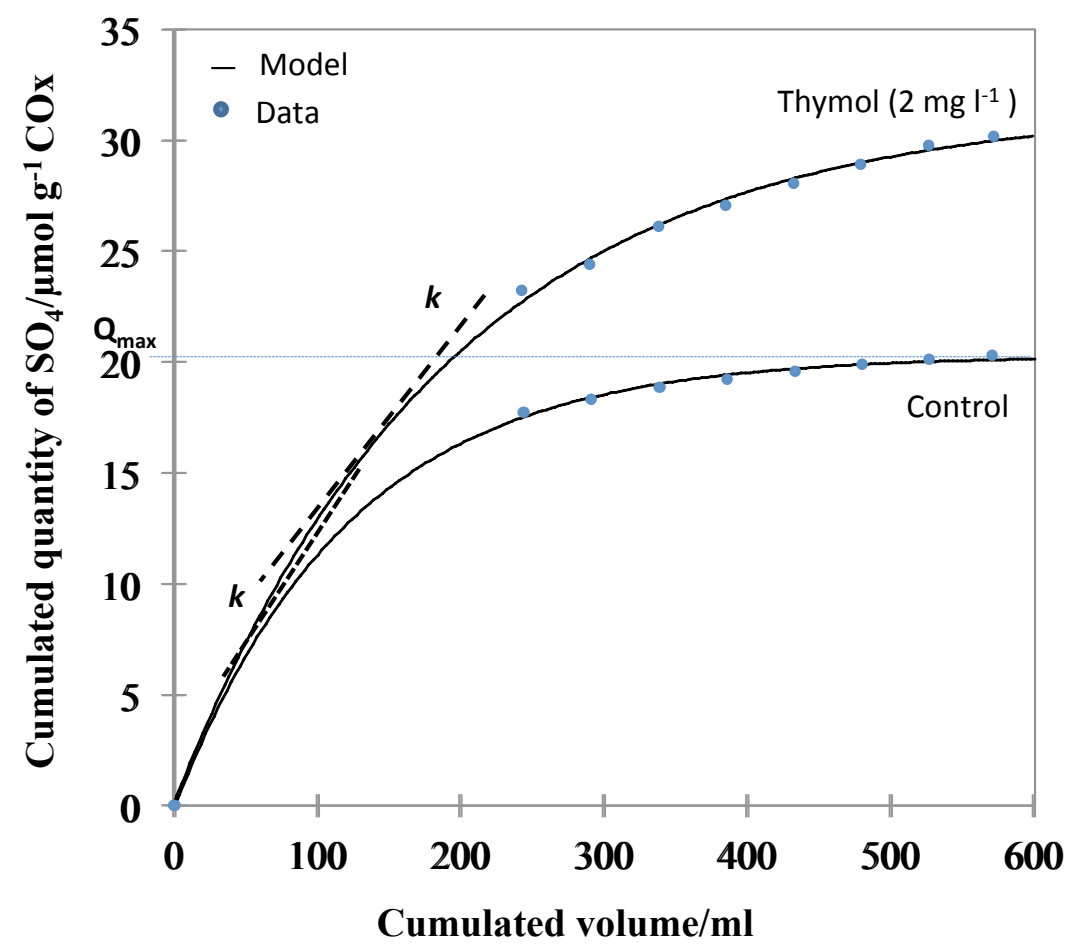


Figure 3 Cumulated quantities of water absorbed by COx (ml) amended with linalool, thymol or carvacrol at three different concentrations (2, 40 and $\left.80 \mathrm{mg}^{-1}\right)$ and non-amended (control) for 57 days. Step 1 (S1) corresponds to the antioxidant input. Step 2 (S2) corresponds to weekly water leaching. For each sampling time, the type II sum of squares were used for the two-way ANOVA to compare antioxidant treatments and antioxidant concentrations. Standard errors were calculated from the residuals of the mean squares of each two-way ANOVA for each sampling time: 0.026 (day 1), 0.071 (day 2), 0.144 (day 9), 0.246 (day 14), 0.204 (day 22), 0.529 (day 29), 1.008 (day 34), 1.603 (day 42), 2.592 (day 50), 5.061 (day 57)

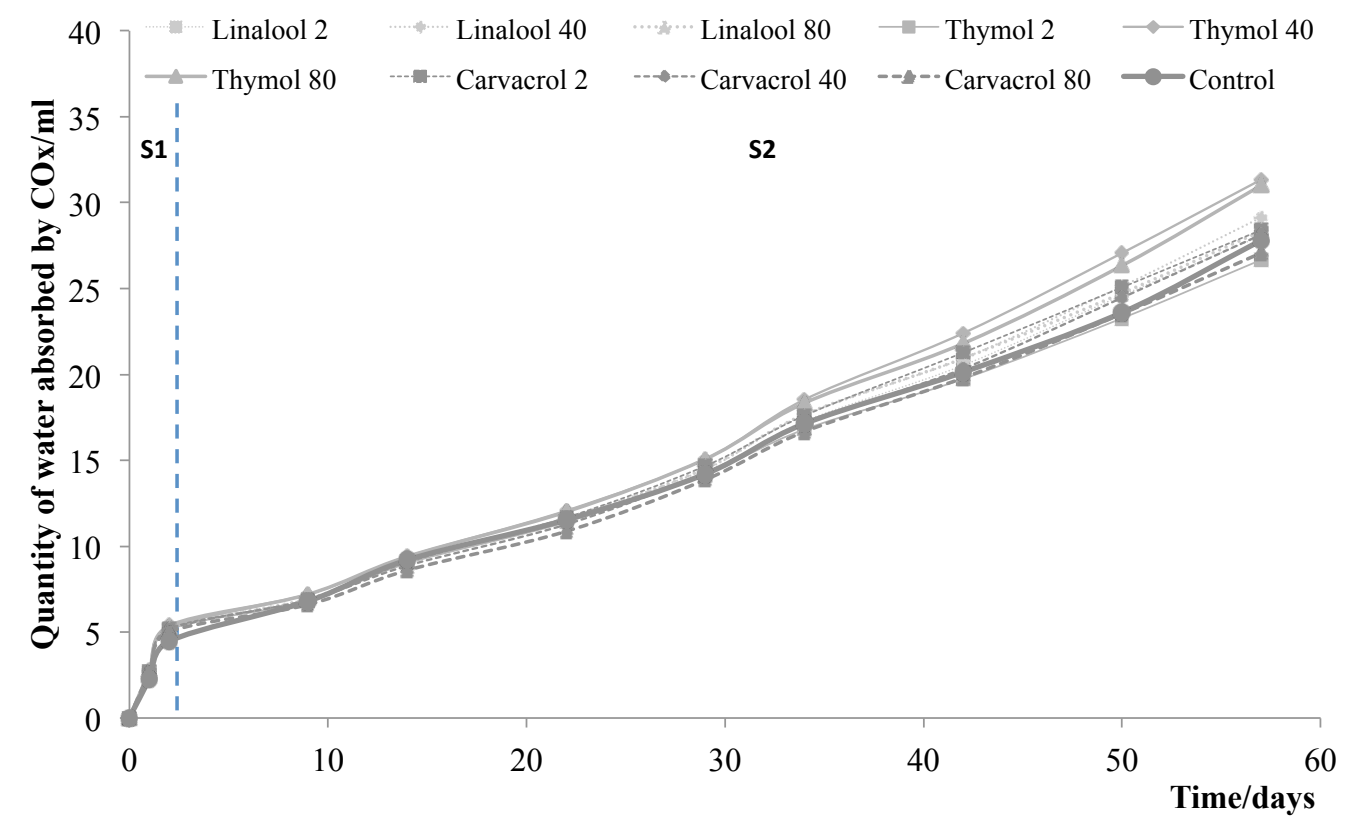


Figure 4 Evolution of $\mathrm{pH}$ values in leachates over time with linalool- (L-), thymol- (T-), or carvacrol- (C-) amended COx at three different concentrations $\left(2,40\right.$ and $\left.80 \mathrm{mg} \mathrm{l}^{-1}\right)$ and nonamended COx (control). For each sampling time, the type II sum of squares were used for the two-way ANOVA to compare antioxidant treatments and antioxidant concentrations. Standard errors calculated from the residuals of the mean squares of each two-way ANOVA for each sampling time: 0.081 (day 1), 0.008 (day 2), 0.065 (day 9), 0.012 (day 14), 0.002 (day 22), 0.010 (day 29), 0.010 (day 34) 0.004 (day 42), 0.005 (day 50), 0.018 (day 57)

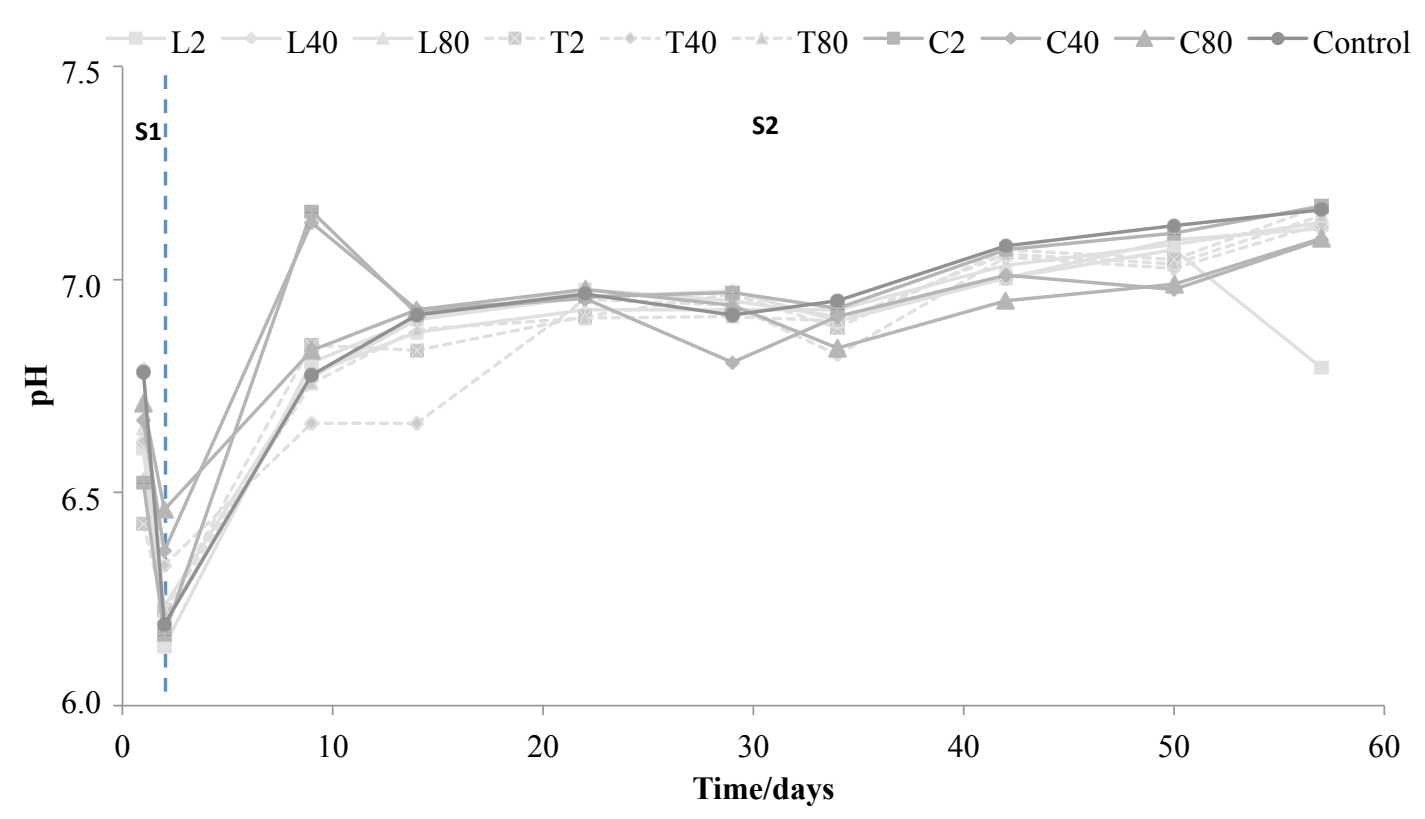


Figure 5 Rates of leaching $\left(\mathrm{nmol} \mathrm{g}^{-1} \mathrm{COx} \mathrm{ml}^{-1}\right)$ of chlorine, nitrate, sulphate and phosphate in COx amended with the three antioxidants (linalool, thymol and carvacrol) at three concentrations $\left(2,40\right.$ and $\left.80 \mathrm{mg} \mathrm{l}^{-1}\right)$ and non-amended (control), calculated for step 2 (S2). Results of the two-way ANOVA to compare antioxidant treatments and antioxidant concentrations are given in the table. D.f, degrees of freedom. The type I sum of squares were used for sulphate. The type II sum of squares were used for chlorine, nitrate and phosphate. Standard errors calculated from the residuals of the mean squares of the two-way ANOVA: 0.017 (chlorine, 0.009 (nitrate), 0.508 (sulfate), 0.370 (phosphate)

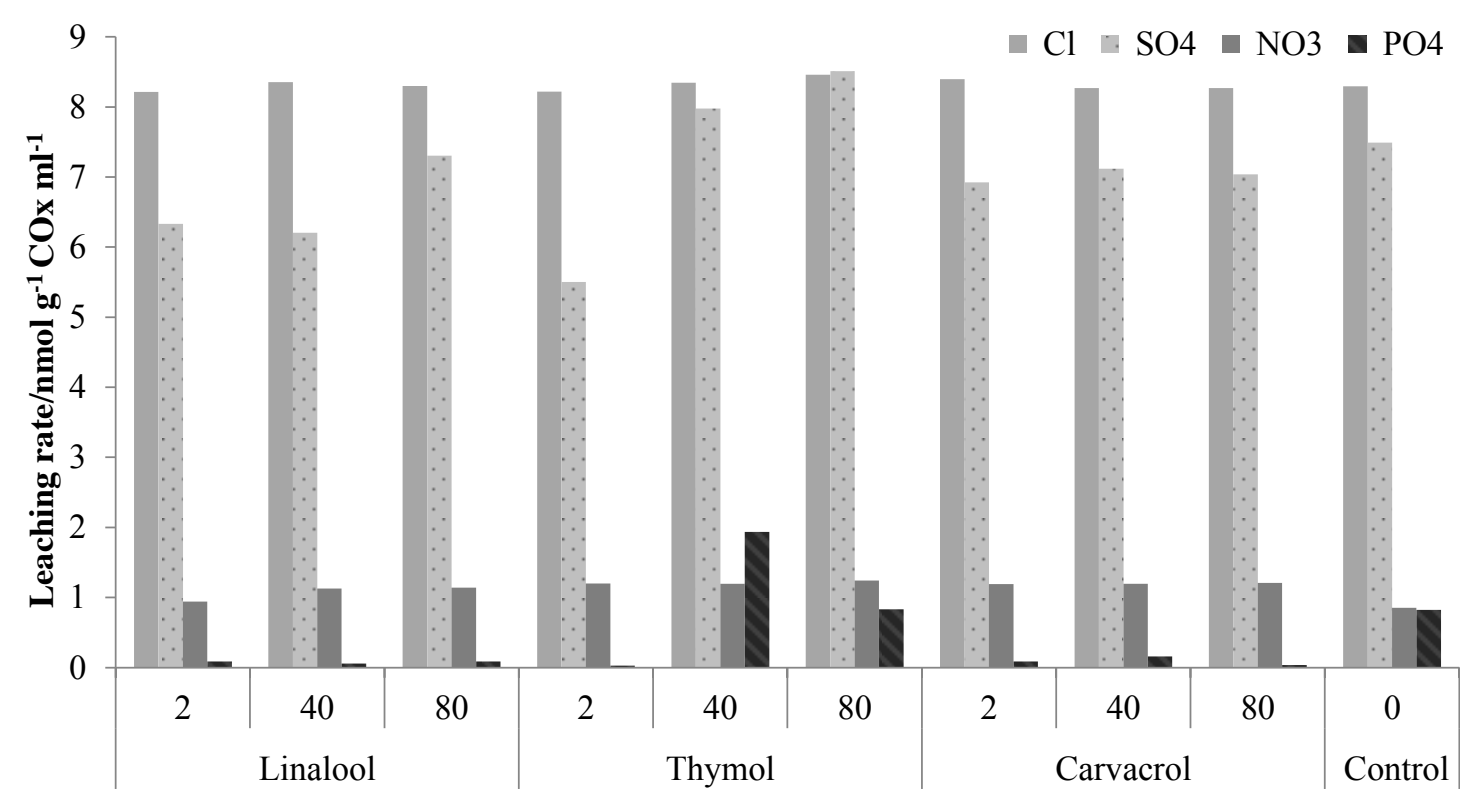


Figure 6 Maximum leachate concentrations $\left(Q_{\max }, \mu \mathrm{mol} \mathrm{g}{ }^{-1} \mathrm{COx}\right)$ for (a) chlorine and nitrate, (b) sulphate and (c) phosphate in COx amended with the three antioxidants (linalool, thymol, and carvacrol) at three concentrations (2, 40 and $80 \mathrm{mg}^{-1}$ ) and non-amended (control), calculated for step 2 (S2). Results of the two-way ANOVA comparing antioxidant treatments and antioxidant concentrations are given in the table. D.f, degree of freedom. The type I sum of squares were used for chlorine, sulphate and phosphate. The type II sum of squares were used for nitrate. Standard errors were calculated from the residuals of the mean squares of the two-way ANOVA: 0.002 (chlorine), 0.018 (nitrate), 6.658 (sulfate), 94.319 (phosphate)

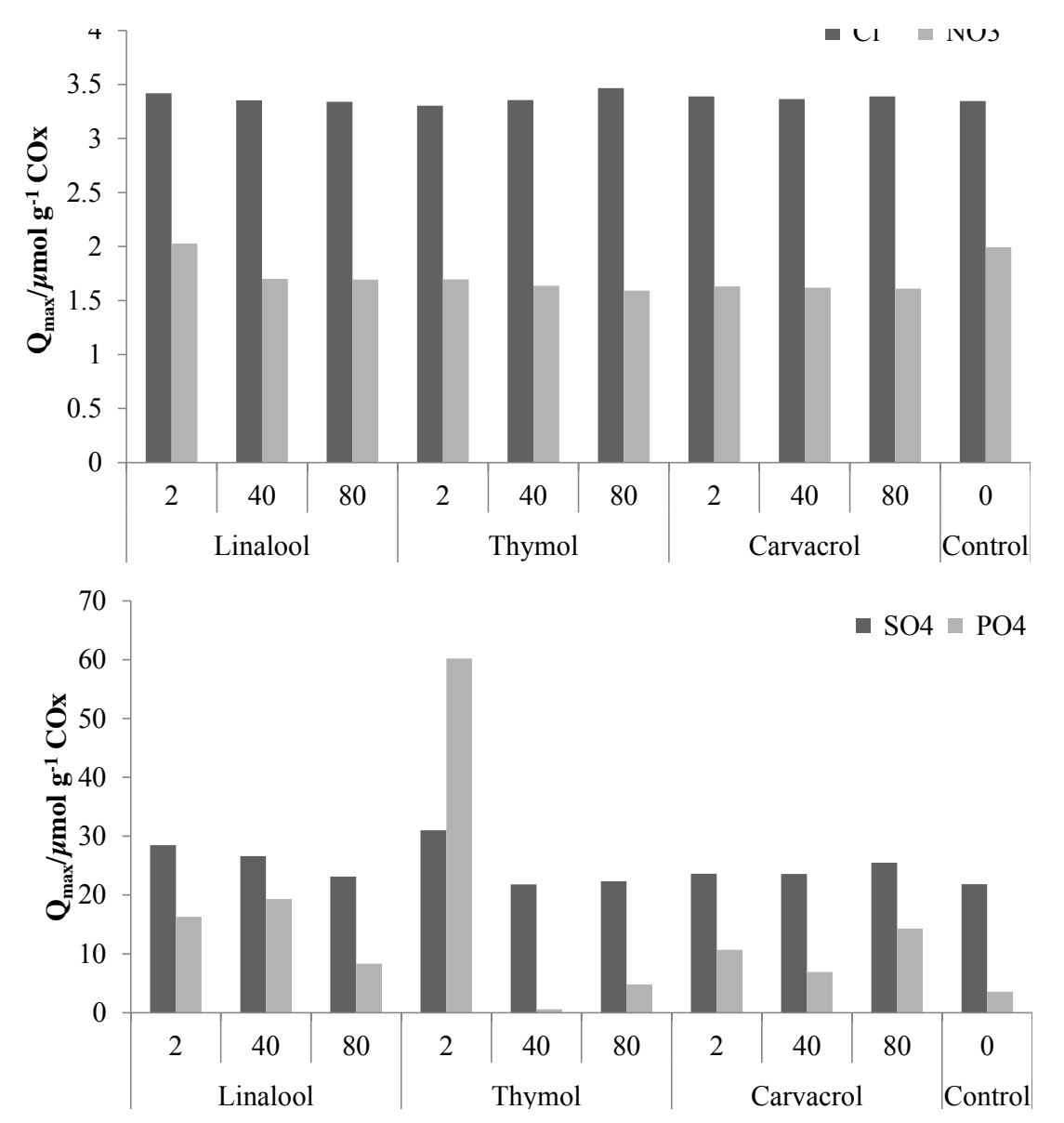

